\title{
THE IMPORTANCE OF RESTRAINING OUR TONGUE ACCORDING TO THE QURAN: AN IMPLEMENTATION AMONG THE STUDENTS
}

\author{
Mohamed Akhiruddin Ibrahim ${ }^{1 *}$ Zulkifli Haji Mohd Yusoff ${ }^{2}$, Muhammad Mus-'ab \\ Anas Mohd Anas ${ }^{3}$ Mohd Zohdi Mohd Amin ${ }^{4}$ and Fatin Wahidah Safiai ${ }^{5}$ \\ ${ }^{1}$ Dr, Senior Lecturer, Faculty of Quranic and Sunnah Studies, Universiti Sains Islam Malaysia, \\ MALAYSIA, akhiruddin@usim.edu.my \\ ${ }^{2}$ Professor, Dr, Academy of Islamic Studies, University of Malaya, MALAYSIA \\ ${ }^{3} \mathrm{Dr}$, Senior Lecturer, Tamhidi Centre, Universiti Sains Islam Malaysia, MALAYSIA \\ ${ }^{4} \mathrm{Dr}$, Senior Lecturer, Faculty of Quranic and Sunnah Studies, Universiti Sains Islam Malaysia, \\ MALAYSIA \\ ${ }^{5}$ Student, Faculty of Quranic and Sunnah Studies, Universiti Sains Islam Malaysia, MALAYSIA \\ ${ }^{*}$ Corresponding author
}

\begin{abstract}
We use our tongue to communicate with people. However sometimes, accidentally, our word used might be hurtful to others especially when we are using foul language or bad words in delivering a message or advising other people so that they will be not boring to listen to us. Unfortunately, this is the sad truth that happen among the preachers especially in this country. Surprisingly, we can hear and see that some of the Malaysian preachers using bad language while giving their lecture to the society. For instance, by calling others as fool, scoffing and humiliating other people. This is a bad example to others since they are seen as good example to the society even though they might be only joking for the purpose of attracting an audience. As mention in the Surah Al Hujurat verse 11 and 12, about the prohibitions in using their tongue, aren't they alert about this prohibitions? If they do know, why they are not guarding their tongue in uttering words? The objective of this research is to identify the implementation toward the importance of restraining the tongue in Surah Al Hujurat verse 11 and 12 among students of Islamic knowledge. Thus, as a subject for this research, we are focusing on the third year students from Quranic and Sunnah Studies (QS) in Universiti Sains Islam Malaysia (USIM), since they will bring the Islamic image after they are graduated soon. Furthermore, the society might be referring to them as a role model and inviting them to deliver a lectures at their residential area. Thus, they also need to be an extra careful, on their behavior, because people may look negatively on Islamic teaching if they saw a disrespectable attitude from the preacher. On this research, we used questionnaire method to collect the data and analyze it according to the respondent's feedback. The result shows that there are some factors which contribute to the misuse of tongue among respondents. The researchers also provides some recommendations to curb this problem among respondents.
\end{abstract}

Keywords: Tongue, Quran, Islamic ethic, moral, akhlaq. 


\section{INTRODUCTION}

A true success of being a Muslim is that one able to enter Jannah and to be saved from the fire of Jahannam. However this can only be achieved if one, while living in this world, obeys Allah's commands and avoid His prohibitions. However, one of the serious factors that can deny the success is the misuse of tongue. After all, tongue is the most powerful organ that has power over Muslim and over the rest of organs. Based on this reason, the Prophet peace be upon him said that all the human body parts are depend on tongue through its straying or straightness. He said, "When the son of Adam (any human) rises in the morning his body parts calls out to the tongue saying "Fear Allah in us, for we are affected by your utterance, if you go steadfast so do we, but if you go astray so do we" (Reported by Al Tirmidzi). However, we can see many Muslims seems not to take serious action on monitoring his/her words during lecturing especially for those who are engaged with society in giving talk like preachers. Using bad words may show disrespect to those being spoken to as they are seen as a good example in society. In verse 11 and 12 in Surah Al Hujurat Allah forbids a believer from using foul language on others as well as to restrain their tongue. In this Surah, the Almighty prohibits a believer from scoffing, insulting, calling offensive nicknames and backbiting one another. By knowing the prohibitions regarding the tongue as mention in the Quran, it will assist them to implement it in their speech. Thus, this research will be conducted among third year students of Quranic and Sunnah Studies (QS) in Universiti Sains Islam Malaysia (USIM). The questionnaire method is used by the researchers to find the result of this research. By giving explanation and educating the future generation, the researchers believe that this will help them to be more careful of their words and to be a good preacher in the future.

\section{LITERATURE REVIEW}

This chapter provides a brief discussion of the literatures as the main guidance in completing this research on the third year students' of Quranic and Sunnah Studies of their implementation on the importance of restraining the tongue in Surah Al Hujurat verse 11 and 12.

\subsection{Al Akhlaq Fi Surah Al Hujurat}

Generally, respondets research is focusing on morality based on Surah Al Hujurat. The thesis is divided into three chapters and the methodology used by the writer is through library research only. The objective of that research is to explain on the meaning of morality from Islamic perspective as Surah Al Hujurat is one of the Surahs that focus mainly on morality. Also, the aims of this writing are to identify the advantages of Islamic morality and to identify the role of morality in order to build a good society (Shakriah, 2004). As for the verse 11 and 12 in Surah Al Hujurat, the writer gives explanations to these verses by referring to the Tafsir. Also, this research urged the reader to abandon bad behaviour that Allah has prohibited us as mention in these two verses such as scoffing, insulting, calling bad nickname, rumouring and backbiting. The writer also discusses the bad effect of having this behaviour in which will give effect on society generally. Furthermore, the writer adds on the reason of these prohibitions by Allah so that it will restrain a Muslim from this bad behaviour. From above discussion, this thesis is lacking when the writer does not provides any supporting details from the authentic Hadith and Quran during the explanation of verse 11 and 12. Also, the writer is only depending on tafsir in order to interpret these verses. Plus, this thesis is just merely a general explanation about the verses in Surah Al Hujurat without any research on difficult words in these verses. As for this research, the researchers will elaborate more on these two verses in Surah Al Hujurat as well as the implementation of the importance of restraining the tongue among the respondents.

\subsection{Surah Al Hujurat Dirasah Tahliliyyah Wa Maudhu'iyyah}

This book is divided into two parts which are analytical part (tahliliyyah) and the content part (maudhu'iah). As for the content part, the writer makes a specific topic that talk about the tongue in the perspective of Surah Al Hujurat. This topic focuses on the verses that mention about tongue which included verse 11 and 12. In the beginning, the writer list out the role of tongue in daily life. Secondly, the writer begins to talk about the sins of the tongue that a Muslim may or maybe not aware of it. The writer also adds some scholars' opinions regarding the tongue. At the end of this topic, the writer provides the reader with Arabic poems that talk about the tongue (Sulaiman, 2007). Generally, this book is not giving a detailed discussion on the verse 11 and 12. The writer only explains these verses in general and does not make any explanation on difficult words in these verses. Thus, in this research, the researchers will elaborate more on these two verses in Surah Al Hujurat as well as the implementation of the importance of restraining the tongue among the third year students of Quranic and Sunnah Studies in USIM.

\subsection{Mafaatih Al Ghayb}

Mafaatih Al Ghayb is a very comprehensive tafsir written by Fahruddin Ar Razi. The explanation, 
grammatical composition and background of revelation as well as all the narrations of the companions and the successors have been mentioned by the writer in an organised manner. As for the verse 11 and 12, this tafsir contains a detailed interpretation of a verse 11 and 12 with a long explanation. The writer discusses the Islamic law contained in these verses with detailed arguments. The writer also supports his arguments with other verses in Quran as well as Hadith from the Prophet peace be upon him. However, there are some disadvantages in this tafsir which is there is only a few hadith and narrations from companions mentioned by the writer. Also, the writer does not mention the validity of the hadith and narrations. Plus, the writer does not mention the sources from where he quoted (Al Razi, 1999). In conclusion, this tafsir is too wide thus, it might give difficulties for some people to find the main point in each verse.

\subsection{Tafsir Al Jalalayn}

Tafsir Jalalayn is written by two scholars, Imam Jalaluddin Al-Mahalli and his famous student Imam Jalaluddin Al-Suyuti. This tafsir is considered as "Tafsir Bil Ma'tsur". In verse 11 and 12 in Surah Al Hujurat, the writer gives the reason for the revelation (Asbabun Nuzul). The writer also gives the meaning of verses briefly based on what they understand of transmitted tradition (Al-Mahalli \& Al-Suyuti, 2007). Some of methods which are not included in this tafsir are the two writers never give their personal opinions on these verses. Second, the interpretations for these two verses of Surah Al Hujurat are very brief thus readers might not get enough understanding from this Tafsir for these two verses. In conclusion, this tafsir only provides a brief interpretation of verses 11 and 12 in Surah Al Hujurat.

\subsection{Al Bahr Al Muhith}

This tafsir is categorised as "Tafsir Al Ra'yl" as well as "Tafsir Bil Ma'tsur". In verse 11 and 12 in Surah Al Hujurat, the writer explains the meaning of terminologies as well as the interpretations of verses. He mentions on the reason for the revelation of verses. He uses Quran and Hadith as main sources to interpret these verses. As this Tafsir is known for its literature, the writer also discusses on grammatical composition (irab). Not to forget, the writer also includes arguments from various Islamic scholars regarding the prohibitions of using tongue falsely in these verses (Abu Hayyan, 1999).

\subsection{Taysir Al Karim Al Rahman Fi Tafsir Kalam Al Mannan}

This Tafsir is a combination of "Tafsir Bil Ma'tsur" and "Tafsir Al Ra'yi" written by Syeikh Abdurrahman AsSa'di. In verse 11 and 12 in Surah Al Hujurat, the writer discusses on the interpretation of verses by supporting with other verses in Quran and Hadith (Al Sa'dy, 2002). The writer also provides explanations from scholars for the Islamic law related to these verses (Fadhlan Mohd Othman et. al, 2011). However there are also many aspects that the writer do not include because the general methodology of itself is to emphasize on the aspect of easiness and understanding towards the Al Quran.

\subsection{Sofwah At Tafasir}

This Tafsir is a combination "Tafsir Bil Ma'tsur" and "Tafsir Al Ra'yi". This Tafsir is actually comprises of many Tafsir as references such as Tafsir Al-Tobari, Tafsir Kasyaf, Tafsir Al-Qurtubi, Tafsir Ibn Katsir and many others. However, the only difference is that this tafsir is more concise, organise and easier to understand (Al Sabuni, 2016). In this tafsir, the writer explains the verses 11 and 12 in Surah Al Hujurat with a simple interpretation. The writer does not mention the meaning of important terminologies like other tafsir books. He also does not include any comments from Islamic scholars regarding the issues in these two verses. The explanation is very short and simple thus easier to understand. However, in this study, the researchers will explain the meaning of some terminologies as well as discussion on some issues regarding the prohibitions regarding tongue in these verses.

\subsection{Ruh Al Ma'ani}

Ruh Al Ma'ani written by Al Alusi is considered as "Tafsir Bil latirani" which consists of "Tafsir Bil Ma'tsur" and "Tafsir Al Ra'yi". In order to interpret verse 11 and 12 in Surah Al Hujurat, the writer always refers to the discussions and comments from the previous scholars and also the contemporary scholars. In the beginning, the writer mentions about the reason for the revelation of verses. Also, he explains the main terminologies in these two verses. The writer then provides a detailed explanation by adding various readings of these verses. Not to forget, the writer used Al Quran and Hadith to interpret these verses (Al Alusi, 2009). However, this tafsir is too detailed in explaining these verses thus, some readers might difficult to find the main point when reading this tafsir.

\subsection{Conclusion}

Basically, this chapter provides a list of literature that will be a guidance for the researcher to carry out this 
research. The objectives of this research is to identify the third year students' of Quranic and Sunnah Studies implementation of the importance of restraining the tongue in Surah Al Hujurat verse 11 and 12.

\section{RESEARCH METHODOLOGY}

\subsection{Introduction}

This research is conducted to identify the implementation of the importance of restraining the tongue in Surah Al Hujurat verse 11 and 12 among third year students of Quranic and Sunnah Studies in Universiti Sains Islam Malaysia (USIM). This chapter highlights the methodology used by the researcher to conduct this research.

\subsection{Research Design}

As there are many types of methods to conduct a research, the researchers only used one method that is suitable to carry out the intended research. Generally, the methodology used for this research can be fundamentally described as quantitative study. This research is solely conducted in the manner of a survey that will be conducted by one group of participants.

\subsection{Setting}

The questionnaire surveys are conducted in a class of students from Faculty of Quranic and Sunnah Studies in Universiti Sains Islam Malaysia (USIM) located in Nilai, Malaysia. The reason of conducting the survey in a class because it is much easier for the researchers to collect the questionnaire after the students have completed the script.

\subsection{Population and Sample}

The subject of this research will be chosen from third year students from Quranic and Sunnah Studies programme. There are approximately 287 students but due to time constrain, only 50 students will answer the questionnaires. Thus, they are suitable participants to carry out this research.

\subsection{Research Instrument}

\subsubsection{Questionnaire Method}

The researchers used a questionnaire method to examine the implementation of the importance of restraining the tongue among the respondents. The total numbers of respondents that are included in this questionnaire are 50 students. The questionnaire is designed to identify on the students' implementation of restraining the tongue. The questionnaire also covered demographic information of the respondents included age, latest examination result and their previous education. It consists of 20 questions. It takes about 5 minutes to be completed. It is written in Bahasa Malaysia to make it easier for the respondents to understand the questions during answering the questionnaire. The researcher has distributed the questionnaire forms among the respondents and all the questionnaire forms were returned by the respondents in completed answer.

\subsection{Conclusion}

In this chapter the researchers highlight the method that she used to carry out this research which is questionnaire method. This method only involves quantitative data. This method will help the researchers to achieve the objective of this research which is to identify the implementation of the importance of restraining the tongue among third year students of Quranic and Sunnah Studies students.

\section{DISCUSSION AND RESULT}

\subsection{Introduction}

This research attempts to identify the implementation of the importance of restraining the tongue in Surah $A l$ Hujurat verse 11 and 12 among third year students of Quranic and Sunnah Studies in USIM. The profiles of all 50 respondents were analyzed in term of gender, latest examination result and their previous education. Below are the overall analyses of respondents' personal background.

\subsubsection{Gender}

Most of the respondents are female with the total of 10 students $(80 \%)$ with the total of 50 respondents. This is because there are more female students as compared to male respondents in public universities. There are only 10 male students in the sample $20 \%$. 


\subsubsection{Previous Education}

Of all 50 respondents, 35 of them (70\%) are from Sijil Tinggi Agama Malaysia (STAM) whereas 15 respondents are from Sijil Tinggi Pelajaran Malaysia (STPM), Tamhidi Centre, Diploma and Matriculation Centre with the total of $30 \%$. It seems that majority of Quranic and Sunnah Studies' students had their previous education from STAM and only a few of them come from other background. This is only logical because normally intakes for this course come from STAM students as they meet the qualifications needed.

\subsubsection{Latest Examination Result}

Researchers discovered that 22 respondents failed to disclose their results which contribute to $44 \%$ overall. However, 10 respondents are in range between 2.0 to 3.0 in their latest which is $20 \%$ whereas 18 respondents (36\%) manage to get 3.1 to 4.0 . In conclusion, the overall result shows that some respondents manage to have good result all this while.

\subsection{Data Analysis}

In this section, the researcher is going to focus on the implementation on the importance of restraining the tongue among the respondents. There will be four subsections that related to four elements of prohibitions related with the tongue as mention in Surah Al Hujurat verse 11 and 12. Each element consists of three parts that are likely contributed to the misuse of the tongue which are the respondents themselves, friends and family. The total number of questions in this section is 20 questions. The analysis of each subsection is as below.

\subsubsection{Do not scoff at people (La Yaskhar)}

This subsection is a descriptive analysis on the implementation among respondents towards the prohibition of scoffing at others in verse 11 in Surah Al Hujurat. Scoffing is to highlight someone's weakness and faults, in such a way that it is laughed at. This could be done by giving statement or showing some action. These and other related characteristics like taunting, mocking are all prohibited in Islam (Islam House.com, 2005, p.64). Scoffing may involve lies as it is made of some people in a way to make others laugh. In a Hadith the Prophet peace be upon him said, "Woe to the one who speaks and lies to make people laugh, woe to him, woe to him" (Recorded by Ahmad). In this part there are five questions to be answered by the respondents. The questions are only related to how they implement their understanding in daily life as well as what are the factors that contribute to it. The first question is investigating whether the respondents are only mingling with friends who are having the same standard of live with them. Second, whether they always compare their advantages with their friends. Third, the respondents were also been asked on their opinion whether it is acceptable for poor people to mingle with rich people. Forth, do they always see their friends downgrading others? The last question is whether their parents are always comparing them with other siblings of theirs.

Of all respondents, $74 \%$ of them were disagreed on the act of ridiculing others. It shows that people and their surroundings treated others around them equally and they did not disgrace one another as it is possible for a person whom they disgrace might be better than them whereas $10 \%$ of respondents agreed that sometimes they cannot prevent themselves from degrading others and even their friends are also making it as a habit. $16 \%$ chose to be neutral which means the respondents might not involve directly with the act of degrading others but somehow their surroundings did give bad influence on them.

This can be seen from the forth question where $30 \%$ of respondents chose neutral option the question asked them whether they always see their friends disgrace others. It shows that friends are big influence to someone as it can reflect someone's behaviour too. In this question, the respondents proved that their friends are sometimes like to disgrace others. Thus, for this subsection it can be concluded that the respondents might not involve directly on scoffing at others but there is other factor for them to scoff at others which is their friends.

\subsubsection{Do not insult one another (La Talmizu)}

This subsection is a descriptive analysis on the implementation among respondents towards the prohibition of insulting one another in verse 11 in Surah Al Hujurat. In other verse an insulter is cursed. Allah says "Woe to every Humazah, Lumazah" (104:1). "Hamz" means belittles and defames people, transgressing and spreading slander among them, while "Lamz" uses words as its tool (Al Qadri, 2015 ). In this subsection, the total number of questions answered by the respondent is five questions. First, the respondents believe that insulting one another is just a harmless matter especially when it was done between their friends. Second, the respondents failed to leave their bad behaviour of insulting others until now. Third, when the respondents heard someone being insult by others, they feel nothing because it has nothing to do with them. Forth, the friends of respondents used to insult them but they did not take it seriously and think that it was only a joke. 
The last one is that their families have fewer manners in speech thus they get used to talk bad with others. The overall result for this subsection is as below.

The majority of respondents which is $66 \%$ answered that they disagreed proved that they were not really involved in insulting others except for sometimes. In the pie chart before, it can be seen that $20 \%$ of respondents which is a quite high percentage chose to be neutral. It means that the attitude of insulting others might come from themselves and sometimes their surrounding might also become the main factor. Surprisingly, $14 \%$ of respondents answered agreed which means even though they were not really involved in insulting others but then their surrounding shows otherwise.

This can be proved by looking at the total percentage of respondents in question four which is $34 \%$ of them agreed that their friends always insult them but they believed that was only a joke from their friends. Meaning that, friends are the main factor that may influence someone's behaviour. Even though in the pie chart above shows that the respondents were aware of the prohibition and implement it in their life, but in the future their friends may influence them as the respondents showed that they only take this prohibition lightly when they did not even try to advice their friends. In conclusion, some respondents may have a good implementation and awareness of the prohibition of insulting one another. However, their surrounding shows otherwise.

\subsubsection{Do not called someone by offensive nickname (La Tanabazu Bil Alqab)}

This subsection is a descriptive analysis on the implementation among respondents towards the prohibition of calling one another by offensive nickname in verse 11 in Surah Al Hujurat. Imam Ahmad recorded that Abu Jabirah Bin Ad Dhahak said, "This verse was revealed about us, Banu Salamah. When the Messenger of Allah migrated to Madinah, every man among us had two or three nicknames. When the Prophet called a man by one of these nicknames, people would say, 'O Allah's Messenger! He hates that nickname.' Then this verse was revealed" (Reported by Ahmad). As for this section, it consists of five questions in which these questions discussed on the implementation of the respondents towards the prohibition of calling others by offensive nickname among themselves as well as their surroundings. The first question is whether they get used to call someone by bad nickname. Second, they used to call someone by bad nickname but then they felt regret. Third, giving bad nickname to someone is nothing for them. Forth, their friends used to call them with offensive nickname but they felt nothing was wrong. The last question is whether their siblings were also used to call them with bad nickname during at home. The answers that researcher collected from the respondents showed the result below.

The result shows that $85 \%$ of respondents disagree which means they were not used to call one another by offensive nickname and even if they did before this, they felt regret for what they had done. In contrast, only $4 \%$ of respondents admit that they used to call others by offensive nickname and they did not feel sorry to the person whereas $11 \%$ of respondents chose to be neutral which means sometimes they did not involve with this prohibition directly but then their surrounding shows otherwise. The worst is they felt nothing when their friends called them by offensive nickname. As a result, they take this prohibition lightly as it seems like it does not cause anything to them.

This can be seen from their answers in question four which are $24 \%$ of respondents contributed to neutral answers where in this question the respondents were asked what their feelings were when their friends always called them by offensive nickname. The result shows that a quite number of respondents answered that they felt nothing as they might think that it is not a big issue. Furthermore, the one who called them by offensive nickname thus they believed that their friends were only joking without any bad intention. However, the truth is no matter who and what the prohibition of calling others by offensive nickname is a strict command from Allah as mention is verse 12 of Surah Al Hujurat. In conclusion, only few of respondents implement towards the prohibition of calling one another by offensive nickname.

\subsubsection{Do not backbite one another (La Yaghtab Ba'dhukum Ba'dha)}

This subsection is a descriptive analysis on the implementation among respondents towards the prohibition of backbiting each other in verse 11 in Surah Al Hujurat. The writer of Sins of the Tongue has differentiated the meaning of backbiting (Gheebah), slander (Buhtaan) and malicious gossip (Nameemah). Backbiting or "Gheebah" is defined as speaking about a Muslim in his absence and saying things that he would not like to have spread around or mentioned whereas slander "Buhtaan" means saying things about a Muslim that are not true and malicious gossip "Nameemah" means telling one person what another said in order to cause trouble between them (Armani Khan, Hassan Mohammed, 2014, p.1). Although backbiting is forbidden there are some conditions which allow a Muslim to talk about someone behind his or her back. For example a person openly exposes his acts of evil, seeking a fatwa, defining someone and so on.

As for this subsection, the respondents were asked to answer five questions to identify their implementation 
of the prohibition as mention in the Quran. The questions are not only focusing on how do they implement it in their daily life, but also will involve the implementation of their friends and families towards the prohibition in which at the end will produce the overall result. For the first question the respondents were asked whether they love to gossip about other people. Second, there is at least once in a week that they cannot escape from talking about others. Third, they were so pleased to hear gossips from their friends talking about others. Forth, their friends are types that love to gossip about other thus, it influence them indirectly. The last question is whether their families are also keeping themselves busy in talking about other people's matter. From the questions above, the researcher managed to collect all the answers from the respondents within the time given. Below is the overall result of this subsection.

Of all respondents, $49 \%$ answered disagreed which shows that the respondents do not really like to get involve with gossip about others. Plus, their friends and families were also did not like to talk about others. However, $11 \%$ of respondents admit that they their surroundings which are friends and families love to talk about others even they were only wanted to share stories but then they did not realize that was considered as backbiting. Surprisingly, $40 \%$ of respondents chose to be neutral which means that they were sometimes did not manage to escape from backbiting others. Plus, in some questions, the result shows that most of respondents were somehow surrounded with bad environment between their friends and families.

It can be proven by looking at the result of question four and five where $46 \%$ of respondents which are majority chose to be neutral in both questions. Plus, in question two, the majority $44 \%$ were neutral about the issue. From the above three questions it can be said that majority of respondents cannot escaped from backbiting others. The worst is even their surrounding were also involved with the act of backbiting others. If this happen, the backbiter should be corrected by stopping him from backbiting and he should be warned that he is involved in a great sin. The one to whom the backbiter comes should defend the brother who is being backbitten. Also, the person who listens to the backbiter should be aware that he is encouraging an evil, and if the person does not stop, then he should walk away from him (Islamic House.Com 2005, p.51). In conclusion, neither the respondents themselves nor their surroundings are having problems to restrain their tongue from backbiting one another in daily life.

\section{CONCLUSION AND RECOMMENDATION}

The researchers acknowledged that most of the respondents were surrounded by the bad environment that influencing them in uttering the bad words. This phenomena can be seen when majority of them agreed that their friends are somehow love to talk about others behind them. Perhaps, the respondents might join them in gossiping about others. The worse thing that ever used during their lecture, is the almost unavoidable issues to be discussed as the conversation may become less interesting without gossiping about others. However, it can't be deny that the respondents themselves are also unable to escape from backbiting when majority of them agreed that they did talk about others at least once a week. From the above result, it is clearly seen that their implementation of refraining tongue from bad language is depend on their understanding as well as their surroundings. If their understanding is poor, it would give a big impact on their implementation in order to restrain their tongue from uttering bad words.

As discussed above, researchers think that some of the respondents are lack of implementation toward the importance of restraining the tongue. This is a serious issue, as we can see that there are several preachers out there that deliver their lecture in front of the society without guarding their tongues. But, at the same time they have thousands of followers, especially among youngsters. From another point of view, they are somehow capable in attracting youngsters to know and learn about religion much deeper. But, in other perspective when they failed to restrain their tongue, they are actually give a bad impression to Islam. Same goes happen to respondents because some of them will become future preachers. If we take it unserious, it may become critical issue in the future. The most important thing is that, they should critically understand the prohibition mentions in these two verses are considered as major sins. According to Kamil Mufti in his article, major sins is defined as any sin for which the Quran or Sunnah prescribes a punishment in this world such as murder, adultery, and theft, or about which there is a threat of Allah's anger and punishment in the Hereafter, as well as anything whose perpetrator has been cursed our Prophet whereas minor sin is every sin that does not have a prescribed punishment for this life or threat attached to it in the Hereafter (Kamil Mufti, 2015, p.2).

So, here are some recommendations that would help the respondents to restrain their tongue from these prohibitions. First, in order to avoid sinning with the tongue is to remain silent. The Prophet peace be upon him said, "He who believes in Allah and the Last Day should speak a good word or remain silent" (Reported by Al Bukhari). Silent may help a Muslim to control his tongue and to speak only when the thing has benefit to him. Every person is responsible for his word that is uttered as it is recorded. Allah says, "Not a word does he utter but there is a watcher by him ready (to record it) $(5: 18)$. The government of the tongue as well as to 
remain silent may further good relationship with other Muslims (Zilio-Grandi, 2016). According to Dr Muhammad Umar Al Qadri, "in order to unite mankind, Islam instructs us to only use speech to be truthful, do good to others, and to be fair and respectful" (Al Qadri, 2015, p.2). Second, it is important to make sure that a Muslim is surrounded with good friends as friends reflect who we are. In one Hadith the Prophet peace be upon him mention that making friends with perfume seller. (The example of the good and evil companions is like a bearer of musk and a person blowing a pair of bellows. As for the musk bearer, he either gives you some, or you buy from him or at least you get a pleasant smell from him. As for the bellows blower he either gets your clothes burnt or you get an unpleasant smell from him) This Hadith talks about the prohibition of keeping bad friends as they would harm one in religious and worldly matters. Thus, it is very important for the respondents to only keep good friends of those who benefit him in matters of religion and life that possess good manners. Last but not least, one should remember Allah whenever he is going to utter bad words. Remember the prohibitions and severe punishments that Allah mentions in Al Quran. Even if other person starts first, he should feel hesitate to join him. If he had done it before, he should repent to Allah as Allah is the Most Forgiving.

\section{ACKNOWLEDGEMENTS}

The researchers would like to acknowledge Centre of Quranic Research, University of Malaya (UM) for the management and Research Management Centre, Universiti Sains Islam Malaysia (USIM) for the financial support as this research was a part of its Grant (PPP/USG-0115/FPQS/30/11415).

\section{REFERENCE LIST}

Abu Hayyan, M.Y (1993). Al-Bahr Al-Muhith. Beirut: Dar Alkutub al-'Ilmiyyah.

Al Alusi, M. (2009). Ruh Al Ma’ani. Beirut: Dar Al Kutub Al Ilmiyyah.

Al-Mahalli, J \& Al-Suyuti, J. ( 2007). Tafsir Al-Jalalayn. Jordan: Royal Aal Al-Bayt Institute for Islamic Thought.

Al Qadri, M.U (2015). Freedom of Speech and Responsible Speech; Islamic Perspectives. Freedom of Speech and Religious Freedom Human Rights and Interreligious Perspectives Seminar. Irish School of Ecumenics, Trinity College Dublin on Thursday 12 March, 2015.

Al Razi, M.F (1999). Mafaatih Al-Ghayb. Beirut: Dar Ihya' Al-Turath.

Al Sabuni, M.A (2016). Sofwah Al-Tafasir. Qaherah : Al Maktabah Al Tawfiqeya.

Al Sa'di, A. (2002). Taysir AlKarim AlRahman Fi Tafsir Kalam Al-Mannan. Riyadh : Maktabah Dar Assalam li Alnashr wa AlTawzi'

Armani Khan, Hassan Mohammed, (2014). Sins of the Tongue. The Muslim Students Association.

Fadhlan Mohd Othman et al. (2011). Methodology of Tafsir by Sheikh Abdur Rahman Saadi in His Famous Tafsir "Taysir AlKarim AlRahman Fi Tafsir Kalam Al-Mannan. Advances in Natural and Applied Sciences Journal, 5(5) :422-431, 2011.

Islamic House.Com (2005). The Evils of the Tongue. Riyadh: The Islamic Propagation Office in Rabwah.

Kamil Mufti. (2015). Concept of Sins in Islam. http://www.newmuslims.com/lessons/216.

Shakriah, N. (2004). Al Akhlaq Fi Surah Al Hujurat. Nilai: Universiti Sains Islam Malaysia.

Sulaiman, N. (2007). Surah Al-Hujurat Dirasah Tahliliyyah Wa Maudhu'iah. Riyadh: Maktabah Ar-Rasyd.

Umar, I. Tafsir Al Quran Al 'Azhim. Riyadh: Darussalam.

Zilio-Grandi, I. (2016). Silence and Speech Etiquette. Annali di Ca' Foscari. Serie orientale, Vol. 52 - Giugno 2016 Venezia. 